\title{
The cultural history and learning affordances of natural history dioramas
}

Michael J Reiss

A diorama is a careful positioning of a number of museum objects in a naturalistic setting. Natural history dioramas come in a variety of forms but typically contain skilfully positioned taxidermy specimens and other objects before a painted backdrop. While time-consuming and expensive to design and construct, dioramas offer tremendous potential as educational tools and are often very popular with museum visitors (Insley, 2007; other chapters in this volume).

While objects are at the heart of museums (cf. Dudley, 2010), curators and other museum professionals typically have a range of responses to dioramas (Paddon, 2009). Dioramas periodically go in and out of fashion (Tirrell, 2000), but then so does taxidermy, which is currently undergoing something of a resurgence in interest (Turner, 2013). Consider, for instance, the use of preserved animals in the work of such artists as Damien Hirst (of pickled shark fame) and taxidermy artist Polly Morgan, whose To Every Seed his own Body features a stuffed blue songbird atop a prayer book under a miniature chandelier (Morgan, 2006).

The education literature on dioramas, while growing, is still meagre (Reiss \& Tunnicliffe, 2011). Dioramas do not feature in the indices of such major texts as Hein (1998), Falk and Dierking (2000), Paris (2002) and Black (2005). What has been published on dioramas mostly consists of studies that examine what visitors learn from them (e.g. Peart \& Kool, 1988; Ash, 2004) and a few publications that trace the history of those who were responsible for them (Wonders, 1993; Morris, 2003; Quinn, 2006). This volume does much to add to and extend the literature in its examination both of the characteristics of dioramas and of their educational capacities and potentials.

\section{History and features of natural history dioramas}


Dioramas have had a longer history than is sometimes supposed as Kamcke and Hutterer (Chapter I.1) review. Their origins go back at least to the panoramas that took parts of Europe by storm at the beginning of the $19^{\text {th }}$ Century; arguably, they have prior antecedents in the careful arrangements of objects found in Renaissance cabinets of curiosities. Nowadays we are used to dioramas capturing a moment but the early dioramas were the centrepiece of shows in which almost every moment contained action and change. In an Alice in Wonderland inversion of reality, Daguerre painted the real objects in his early dioramas to help conform them to the image he was creating.

Within natural history dioramas a useful distinction is made by Kamcke and Hutterer between artificial groups (that show an unnatural large number and diversity of individuals and species in a particular landscape), geographical groups (that present animals or plants from a specific geographical region), biological groups (that show a piece of nature with a natural combination of habitat, plants and animals but lack a painted background and the illusion of space) and habitat dioramas (that present convincing 'windows on nature' (Quinn, 2006) and are characterised by a nearperfect combination of scientific accuracy, art and technology).

Certain works of art are routinely accorded less protection than others. Murals, for instance, seem peculiarly ephemeral even when painted by recognised artists (Power, 2013). Dioramas too are all too infrequently accorded the protection they deserve. As Hutterer (Chapter I.2) points out, nowadays early panoramas, photographs and technical optical equipment are valued as highly priced collectors' items and may be displayed in art exhibitions whereas habitat dioramas in natural history museums are too often threatened by dismantling. Focusing on the European bison and moose in the oak-birch swamp forest diorama in the Museum Alexander Koenig in Bonn, Hutterer researches its origins and cultural significance in a manner reminiscent of the various contributions in Alberti (2011), remarkably succeeding in linking the male moose to none other than Hermann Göring.

The Bonn diorama is illustrative of the care frequently taken in the construction of major natural history dioramas. It was planned as one of a series of 12 by Alexander Koenig (1858-1940), a private scholar with a doctorate in natural history, for his 
eponymous zoology museum. Koenig saw his dioramas in the tradition of the great Swedish artists Gustav Kolthoff (1845-1913) and Bruno Liljefors (1860-1939), who both worked together on early habitat dioramas. Yet, as Hutterer shows, whatever Koenig's intentions, he, his dioramas and his museum became caught up in the maelstrom that engulfed Europe in the 1930s. Koenig died in 1940; it's a wonder his dioramas survived both the Second World War and subsequent 'renovations' at the museum.

Dioramas, as Morris (Chapter I.3) points out, make accessible objects and places that would otherwise be beyond the direct experience of most people. Today, they seem, to some viewers, to provide less than the moving image. Yet in their time before the advent of television they were seen as being more realistic than still photography. Whatever the arguments about realism, a diorama can be constructed to convey precise messages about ecological context, habitat, behaviour, structure and movement, whereas a photograph is more or less limited by what is actually happening in the frame at a particular instant in time. In this respect dioramas have a similarity with those mediaeval paintings of the lives of the saints that present several asynchronous events in a single painting, to be read sequentially as the eye moves across the picture's surface.

Morris' argument about the similarities and differences between dioramas and photography is taken up by Howie (Chapters I.4 and I.5) in her study of the dioramas of the Powell-Cotton Museum. On entering the museum, the visitor, like Pip calling on Miss Haversham, is swept back to an earlier period as Gallery 2, in particular, is virtually unchanged from its 1896 construction. The visitor is overwhelmed by a profusion of specimens in a beautiful and carefully constructed setting. Powell-Cotton seems to have used the exhibits in his museum to recreate a memory of his extensive travels on over 28 exhibitions to many countries in Asia and Africa.

Drawing on Wonders' own tremendous doctoral thesis (Wonders, 1993), Howie considers the natural habitat diorama as an ecological theatre. Plato, of course, was deeply suspicious of the theatre. He saw it as a dangerous place since philosophers were concerned with truth whereas actors and orators persuaded the public through the use of rhetoric. Nor was that true only of the theatre. In Book X of The Republic, 
Plato relates Socrates' metaphor of three beds: one (the Platonic ideal) exists as an idea made by God; one is made by a carpenter; and one is made by the artist in imitation of the carpenter's. The artist bed is therefore twice removed from the truth (the Platonic ideal).

As Powell-Cotton aged, he became sensitised to conservation issues and his dioramas can be read in that light, as well as being the product of a colonial hunter. As Howie argues, his diorama present an idyll, one in which birth and death, the sick and the old, the need for food and shelter are edited out. What therefore results is a distinctive fiction in which the craft of the taxidermist and artist combine to construct a particular fabrication, a deceptive reality.

Remarkably little is known of many of the artists who helped turn drastically foreshortened dioramas into convincing three-dimensional spaces. Michael Anderson (Chapter I.6) describes how James Perry Wilson, one of a number of painters of dioramas in the American Museum of Natural History in the mid-20 $0^{\text {th }}$ Century, developed and refined his technique. Painting a diorama is painting using anamorphic perspective (such as the famous example in Holbein's The Ambassadors) - it's not easy! What Wilson did was to look at the problem of distortion analytically. Using his architecture training, he devised distinctive projection grids, relying less on 'the artist's eye' than did other painters of dioramas.

The result was that Wilson produced, using his science-based techniques, more convincing backgrounds than any other diorama painter of his time. Eschewing the then advice to avoid relying too much on nature but be artistic, Wilson produce a series of stunning and realistic backgrounds. Critics of the time alleged that his backgrounds lacked creative inspiration but, as Anderson shows, Wilson realised that the more 'artistic' the background, the less effective the illusion. Wilson simply painted what he could see. Time has proved him right.

\section{Modern dioramas}


In 2004 the National Museum of Natural History in Mdina, Malta embarked on an educational programme by building and presenting a set of dioramas that highlighted local ecosystems. Borg (Chapter II.1) describes how the resulting dioramas can function as educational tools for wildlife conservation and appreciation. The intention is to overturn the common misconception that Malta is largely devoid of wildlife. In general, dioramas are often accompanied by less written information than is the case for many museum exhibits. In the case of the Maltese National Museum of Natural History, the dioramas lack any labels or information panels. What happens instead is that during organised visits, viewers are invited to note the animals and plants they observe in the displays and then, with the help of museum staff, they go through each display again and see which additional species were not noted.

Loveland, Buckley and Quellmalz (Chapter II.2) examine the affordances of computer-based technologies to help visitors step into a richer understanding of ecosystems. A sceptic might presume that computer-based technologies simply position the museum visitor as being even further removed from museum objects. However, research shows that computer-enhanced exhibits can deepen visitors' engagement with real objects. Furthermore, we are still in the early days of realising how to use the potential of these new technologies to enhance visitor engagement, learning and wonder. Used appropriately, such technologies can develop skills of argumentation, collaboration, model-based thinking and innovation.

Loveland, Buckley and Quellmalz compare how two very different museums deal with ecosystems. One is the internationally renowned American Museum of Natural History that opened in 1869 and currently has 32 million specimens and 500,000 square feet; the other is the Marian Koshland Science Museum of the National Academy of Sciences that opened in 2004 and has just a handful of physical artifacts and 6,000 square feet of floor space. While the Mammal Halls at the American Museum of Natural History provide a precise and apparently timeless recreation of ecosystems from the past, the Earth Lab in Marian Koshland Science Museum uses up-to-date data, simulations and multimedia visualisations to present how ecosystems across the globe are impacted by various manifestations of global climate change: drought, heat waves, rising sea levels, receding glaciers and increasing ocean salinity. Visitors can explore how their own choices might or might not impact climate change 
and compare the effects of their choices in real time with those of choices made by other visitors. More generally, digital technologies can help visitors build more complete, dynamic models of the system interactions and changing population levels portrayed in dioramas and other displays across time and changes in environmental conditions.

Natural history dioramas are often very popular with visitors. Ximin (Chapter II.3) describes how the new diorama exhibition in the Zhejiang Museum of Natural History increased visitor numbers by a factor of ten. What is less clear, though, is the longterm effect of visiting such dioramas. In particular, can dioramas such as these inspire visitors to love nature and cherish life and the natural environment in which they live?

Dioramas are amongst the most complex of museum exhibit constructions, natural history dioramas particularly so with their combination of taxidermy specimens, background scenery and other objects. In the case of the historical dioramas in the Hessisches Landesmuseum Darmstadt, Munsch, Schmiese, Angelov, Riedel and Köhler (Chapter II.4) summarise how damage over the last 100 years has resulted from UV radiation, climatic fluctuation, the original techniques used to preserve biological specimens, occasional treading on the dioramas, dust, insect infestation and vibrations caused by construction and restoration works on the building. The resulting restoration has allowed these dioramas to be viewed anew in something close to their original full glory.

\section{Learning at dioramas}

Museums typically juggle a multitude of roles, one of which, as Tunnicliffe and Scheersoi (Chapter III.1) point out, is for them to be sites for informal learning about values, norms and technical knowledge. Museums are now more aware that visitors bring their own understandings of meaning with them, so that exhibits need to connect with these if a visit is to appreciated by the visitor and result in some sort of learning. Dioramas can be fruitful in this regard as they offer a range of possible hooks onto which visitors can latch. Of course, learning can be as transient at a diorama as at any other museum exhibit if the thread that connects it to a visitor is a 
thin one. However, there are a number of features of dioramas, including natural history dioramas, that can serve to grab and hold the attention of visitors. Indeed, dioramas provide particular opportunities, as Tunnicliffe and Scheersoi discuss, for museums to act as sites of socialisation. Children, in particular, can engage in dialogue, expressing their own thoughts and developing their own ideas while listening to those of others and co-constructing their understandings with them.

Certain dioramas catch the attention of visitors more than others but what causes some dioramas to be more successful in this regard? Scheersoi (Chapter III.2) addresses this question, drawing on data collected at natural history dioramas in three German museums with diorama galleries. Interest was determined using a range of methods: observation of visitors, notes made of visitor conversations at dioramas, audio-taped interviews with visitors after they had viewed a diorama and children's drawings after they had viewed a diorama. As one might expect, certain dioramas tended to be more interesting than others though interest is a function of the visitor too, not only of the exhibit.

Scheersoi found that visitors are especially likely to stop at dioramas with big, young or rare animals. The resulting 'animals encounters' were particularly appreciated, given the fact that few visitors ever come face to face with such animals in the wild. However, personal significance could trump considerations of size or rarity as in the visitor who stated: "My interest was caught by the tick, because we have a cat that often brings these ticks at home". Local animals, too, were often particularly appreciated as parents sought to point them out to their children or simply wanted to know more about them for themselves. Other well designed features of the dioramas were important in attracting attention; ice, a stream, the background painting, plants, a fence, tyre tracks and a puddle were all commented on positively in this regard. As with a musical tune, the trick is for a diorama to be neither too familiar and predictable nor too unfamiliar and unpredictable. Indeed, the data show that the dioramas varied hugely in how successful they were in arresting and holding the attention of visitors.

The importance of the experience, knowledge and expectations that visitors bring to dioramas is emphasized further by Tunnicliffe (Chapter III.3). Visitors often identify 
and name objects, particularly animals, within natural history dioramas. This initial identification catches their interest and they may go on to interpret what they see, even to investigate it further. Realisation of these various phases of a visit has been aided by a trend for research on dioramas to incorporate more qualitative methods than used to be the case. Indeed, if anything, there now seems to be a bewildering range of research methods in use with apparently little attempt to produce some sort of analytical frame to indicate which methods might best be used for which purposes.

The importance of storytelling for us - for how we make sense of the world and for why we learn - is increasingly recognised. Cotumaggio (Chapter III.4) explores the power of narratives for learning about natural history, noting that storytelling is widely used for teaching about literature and history, but rarely for teaching about science. And yet, many learners of science find much of the subject to be boring, to have no connection to the things in their lives that matter and so to be irrelevant; perhaps storytelling could help.

The American Museum of Natural History provides a fine research site to study these issues. In its Museum Education and Employment Program (MEEP), college-aged youth are given training on the content of the museum's exhibit halls and in pedagogy. They develop their own distinctive tours set in the form of a narrative and infused with inquiry to engage visitors, mostly camp groups. The tours are designed to draw on the visitors' prior knowledge and encourage observations, questions and a desire to learn more.

The outcomes of Cotumaggio's study show that the more inquiry-driven the tour, the more the narratives, and in particular the conversations at each diorama, change with each group. Visitors come to the museum with pre-existing ideas about how the world works. By using inquiry techniques, the facilitators are able to draw on this prior knowledge and allow it, and the observations and interests of the audience, to drive the direction of the narrative.

A challenge to any simplistic idea that dioramas present objective truth is provided by Livingstone (Chapter III.5) who draws on the approaches to understanding dioramas used by Haraway (2004), Haraway being one of the small number of authors to 
employ critical theory when attempting to understand how dioramas are viewed. However, what remains unclear is whether visitors see dioramas in the way that cultural theorists like Haraway do. Livingstone addresses this question in her visitor study on the African Savannah diorama at the Royal Ontario Museum. This diorama has five prominent lions arranged - at least in the eyes of a cultural theorist - in the manner of a conventional human nuclear family, with a standing adult male as the focal point. Data were collected by means of observations, intercept interviews and visitor-employed photography.

Quite number of visitors did, without prompting, state that the lions were a family, thus applying an anthropocentric and gendered analogy to make sense of the diorama. However, some visitors were more than capable of deconstructing what they saw and questioning its presumed intended message. For instance, one visitor (a student in her twenties) critiqued the presentation, resisted a focus on the lions as the most important element of the drama and found her own significance in the diorama:

Well, it looks like it's supposed to be reflecting a typical day in the life of a lion. I don't know how realistic the picture its, but I've never been to Africa before. I get distracted by the background because it doesn't look like something that would actually be a prairie in real life. It just doesn't seem like there would be giraffes right there and lions right there. But I think what they're trying to go for is looking at something that looks nice, not really realistic. And I guess, yeah like I said, it's supposed to be representing a typical day ... like if you look at the birds that are over there - they actually looked like they were doing something instead of just sitting and standing around ... look like they're actually kind of foraging around and pecking at things. And I think that's interesting. And you've got the snakes right there, and that bird right there. It's the little things that just mean a lot more than the actual bigger parts of it. And those birds, they look like they're going to eat something. You know? The lions just look like they're standing around and waiting for something to happen.

The staging required by natural history dioramas suggests that they can contribute to visitors' development of a sense of place, yet little research on this possibility has been undertaken. Such research is needed, not least because a number of studies suggest that developing a strong sense of place can lead to environmentally responsible behaviours. Garibay and Gyllenhaal (Chapter III.6) note the richness of 'place' - with its biophysical, psychological, sociocultural and political economic dimensions. They developed an instrument to measure 'place bondedness', aspects 
and potential outcomes of the diorama experience and a range of possible contributing factors such as familiarity with the place, personal connectedness to nature and preferences for outdoor experiences. Data were collected from some 300 individuals at each of two sites: the Nature Walk diorama exhibition in the Field Museum and the Explore Colorado dioramas at the Denver Museum of Nature and Science.

In both museums the dioramas evoked memories that connected to people in respondents' lives and to events such as vacations, childhood explorations in nature and encounters with animals. More generally, these connections to place could be represented as concentric rings from places of individual significance through places shared with particular others to community places and, finally, iconic places - such as the Amazon or the Grand Canyon - that the visitor might not actually have visited. Interestingly though, many visitors didn't vocalise these thoughts to those with whom they visited - only to the researchers.

The Denver Museum of Nature and Science boasts fully 104 wildlife dioramas. Many of these are loved by visitors yet many are now tired after decades of use. Since 2007 the museum has introduce an enactor programme in an attempt to enhance visitor experience. The enactors act (fictitious) historical figures. For example, Miss Florence Epp is a young adventurer who grew up in Africa. She draws inspiration from her late 1800s' (genuine) counterparts, Mary Kingsley, Isabelle Eberhardt and Gertrude Bell, women who explored foreign lands and studied indigenous cultures. Miss Epp is most at home in the Botswana Hall, telling stories and teaching games from Africa and showing her collection of 'money cowries'. Tinworth (Chapter III.7) describes the effect the programme is having.

The response of visitors to the enactor programme has been positive. Indeed, all 54 of the sampled visitors who interacted with the enactors commented positively about their interactions, stressing the uniqueness, educational value, interactive element and personal relevance/connection that the interaction brought to their museum experience. Additionally, they spoke to the ability of the enactors to interact effectively with children. Observations of the enactors at work confirmed these reports. Furthermore, visitors spent almost twice as long at exhibits when enactors 
were present. The enactors too were positive about the educational benefits of the programme.

Other museums have developed interactive programmes to get more from their dioramas. In the Powell-Cotton Museum, Dunmall (Chapter III.8) describes the introduction of storytelling tours that frequently include dramatised narrative, audience acting out, call and response games, object handling, questions and answers and craft activity. The storytelling is aimed at a mixed-aged audience, under the guise of a children's activity. It takes often familiar tales from a mix of genres including folk and fairy tales, myths, legends and more recent 'children's stories' (e.g. Brer Rabbit) and links them to the diorama. One of the stories features Powell-Cotton himself. On his two-year honeymoon cum expedition he may only have survived the maulings of a lion that now features in one of the dioramas because of the presence of a copy of Punch in his breast pocket.

Over the centuries museums have changed in terms of how they present biodiversity. Marandino, Achiam and Oliveira (Chapter III.9) discuss how nowadays, just as science is more sensitive to anthropogenic effects so museums are using the notion of immersion as a way of extending dioramas to include the visitor as an actor within the displayed scene, thus recognising humans as agents in nature. However, due to museographic transposition, the ecology embodied in the expositive discourse (the diorama) differs from the ecology found in the scientific discourse from which, in part, it derives. Furthermore, visitors to natural history museums generally do not expect interactive devices, but the more contemplative experience typically promoted by such museums. Nevertheless, the research reported by Marandino, Achiam and Oliveira, in agreement with that reported elsewhere, shows that interactive and technological experiences can be effective.

In the final chapter in this volume, before this concluding one, Mifsud (Chapter III.10) uses drawings to investigate what primary children learn when visiting the dioramas in the Natural History Museum of Malta. Malta is a small archipelago that lacks zoos or animals parks. Accordingly, the dioramas in the Natural History Museum are an important educational resource. One interesting finding was that almost half the drawings showed a feature not present in the dioramas. An initial 
reaction might be one of surprise. However, if we think of representations (drawings) as attempts by individuals to make sense of what they see in the light of what they already know, this becomes less surprising.

\section{Coda}

Dioramas are usually snapshots: they are a moment frozen in action, so visitors can view, ponder and look again. In this way they are unlike live animal exhibits in zoos, which perform a different function for their visitors (Reiss \& Tunnicliffe, 2011). Moreover, in contrast with the single taxidermically prepared animal typically found in other natural history museum displays, the specimens in natural history dioramas are usually shown in clusters in a representation of their natural context, which conveys many messages for visitors to interpret. If visitors look carefully and thoughtfully, they may develop their observational and interpretative skills.

Dioramas also stimulate the construction of visitor narratives and inquiry. Inquiry is both the art and science of asking questions about a phenomenon or object, in this case a natural history diorama portraying an aspect of the natural world, and finding answers to those questions. It involves careful observations and measurements, hypothesising with reasons, interpreting and theorising. Inquiry-based learning is a way of acquiring further knowledge and understanding through the very process of questioning. Learners may raise the questions themselves spontaneously from their own first-hand observations connected with their mental model of the subject of the dioramas or the question may be put to them by a significant other, such as a facilitator or adult in charge of the child (Vygotsky, 1962), to scaffold their thinking and develop concepts that may be required by formal, school curricula.

Whereas a single museum object is an instance of reality, a diorama is a depiction of reality. Of course, it might immediately be objected that even a single object involves the creation of a reality: which particular object is selected (for instance, crystals more often than ores in earth science exhibits), its aspect (terrestrial mammals are rarely shown asleep) and so on. Nevertheless, dioramas take the depiction of reality much further than a single object does. They require the designer to think about things like 
the numbers of objects, their positioning and staging, to indicate their interrelationships and often a scenic background or surround. What might be termed the realist perspective - the notion that a diorama should depict reality - is illustrated by the work of James Perry Wilson (Chapter I.6).

Yet, as has been argued, the situation is more complicated, not least because the attention to detail and the search for objectivity pursued by many who construct dioramas may lull the viewer into believing that they are indeed being presented with a picture of reality (Reiss \& Tunnicliffe, 2011). Furthermore, animals are shown doing interesting things more often than would actually be the case in nature. Male gorillas beats their chests, a leopard mauls a child, large number of different species mingle in a small area, a hippopotamus is found out of water in broad daylight and so on - the examples could continue and apply to a high proportion of natural history dioramas. My point in noting this is not to complain but to note the slippage from 'actual reality' to 'interesting presented reality'. Dioramas are therefore a bit like soap operas. Things happen in them everyday that in reality happen only occasionally (cf. Crayford, Hooper \& Evans, 1997). Indeed, even granted the unrealistically frequent acts of predation they sometimes present, natural history dioramas often have a Garden of Eden feel to them. There is no disease or malnutrition; animals are inevitably shown in the prime of health and physical fitness, the same features that are sometimes found in children's drawings of ecosystems (Reiss, Boulter \& Tunnicliffe, 2007). I suspect this reflects by viewers an idealistic view of museum reality, a view that the museum should be presenting what should be as much or more as what is.

Again, this is not to criticise natural history dioramas - it is good for us to consider what life might consist of as well as what it does. But these points mean that there is particular value, when such dioramas are used for educational purposes, in encouraging viewers to reflect on what they see and conclude. A diorama is a metaphor for reality not a faithful depiction of it. Metaphors can illuminate but they need to be examined and talked through, otherwise they can seduce unwittingly.

\section{References}


Alberti, S. J. M. M. (ed.) (2011). The afterlives of animals. Charlottesville VA: University of Virginia Press.

Ash, D. (2004). How families use questions at dioramas: ideas for exhibit design. Curator 47: 84-100.

Black, G. (2005). The engaging museum: Developing museums for visitor involvement. Abingdon: Routledge.

Crayford, T., Hooper, R. \& Evans, S. (1997). Death rates of characters in soap operas on British television: is a government health warning required? British Medical Journal 315: 1649.

Dudley, S. H. (ed.) (2010). Museum materialities: Objects, engagements, interpretations. Abingdon: Routledge.

Falk, J. H. \& Dierking, L. D. (2000). Learning from museums. Walnut Creek CA: AltaMira Press.

Haraway, D. (2004). Teddy-bear patriarchy: taxidermy in the Garden of Eden, New York City, 1908-1936. In The Haraway Reader, D. Haraway (ed.), pp. 151-197. New York NY: Routledge.

Hein, G. E. (1998). Learning in the Museum. London: Routledge.

Insley, J. (2007). Setting the scene. Museums Journal 107(2): 33-35.

Morgan, P. (2006). To Every Seed his own Body. Accessed 27 October 2013 at www.flickr.com/photos/polly_morgan/123673884/.

Morris, P. A. (2003). Rowland Ward: Taxidermist to the world. Ascot: MPM.

Paddon, H. (2009). Curatorial responses to natural history dioramas. In The important role of natural history dioramas in biological learning, S. D. Tunnicliffe and A. Scheersoi (eds). ICOM Natural History Committee Newsletter 29: 11.

Paris, S. G. (ed.) (2002). Perspectives on object-centered learning in museums. Mahwah NJ: Lawrence Erlbaum.

Peart, B. \& Kool, R. (1988). Analysis of a natural history exhibit: Are dioramas the answer? The International Journal of Museum Management and Curatorship 7: 117-128.

Powers, A. (2013). British murals \& decorative painting 1920-1960. Clifton: Sansom \& Co.

Quinn, S. C. (2006). Windows on nature: The great habitat dioramas of the American Museum of Natural History. New York NY: Abrams. 
Reiss, M. J. \& Tunnicliffe, S. D. (2011). Dioramas as depictions of reality and opportunities for learning in biology. Curator 54: 447-459.

Reiss, M., Boulter, C. \& Tunnicliffe, S. D. (2007). Seeing the natural world: A tension between pupils' diverse conceptions as revealed by their visual representations and monolithic science lessons. Visual Communication 6: 99114.

Tirrell, P. B. (2000). Dealing with change: University museums of natural history in the United States. Museum International 52(3): 15-20.

Turner, A. (2013). Taxidermy. London: Thames \& Hudson.

Vygotsky, L. S. (1962). Thought and language. Cambridge MA: M.I.T. Press.

Wonders, K. (1993). Habitat dioramas: Illusions of wilderness in museums of natural history. Doctoral Thesis. Sweden: Uppsala University. 